\title{
INVESTIGATION OF INCREASING TECHNOLOGY USE AND DIGITALIZATION IN AUDITING
}

\author{
DOI: 10.17261/Pressacademia.2019.1058 \\ PAP- V.9-2019(5)-p.20-23
}

\section{Burcu Adiloglu' ${ }^{1}$, Nevzat Gungor ${ }^{2}$}

${ }^{1}$ Istanbul University, Avcılar Campus, Faculty of Business Administration, Accounting Department, Istanbul, Turkey. adiloglu@istanbul.edu.tr, ORCID: 0000-0001-9680-1408

2 Istanbul University, Avcılar Campus, Faculty of Business Administration, Accounting Department, Istanbul, Turkey. nevzat.gungor@istanbul.edu.tr, ORCID: 0000-0001-9883-1985

\section{To cite this document}

Adiloglu, B., Gungor, N., (2019). Investigation of increasing technology use and digitalization in auditing. PressAcademia Procedia (PAP), V.9, p. $20-23$

Permemant link to this document: $\mathrm{http} / / /$ doi.org/10.17261/Pressacademia.2019.1058

Copyright: Published by PressAcademia and limited licenced re-use rights only.

\section{ABSTRACT}

Purpose- The aim of exploratory study is to increase the understanding of the effects digitalization has on the tools and working methods of the audit profession.

Methodology- Websites of 235 audit firms authorized by KGK (Kamu Gözetimi Kurumu- Public Oversight, Accounting and Auditing Standards Authority) were examined. The status of the services provided by the audit companies after the technological developments were analyzed. Findings- It has been found that almost all audit companies provide services for independent audit and tax audit. (Respectively $95 \%$ and $85 \%)$. These are followed by financial services and internal audit issues. (Respectively $61 \%$ and $45 \%$ ). Only Big Four invest the necessary infrastructure and human resources in addition to providing services in these matters.

Conclusion- As a result, with the effect of digitalization, Information technologies have gained importance. But the audit firms have not yet made the necessary investment in these areas. $90 \%$ of audit firms do not provide services in these areas and do not make infrastructure and human resources investments.

Keywords: Digitalization, information technologies, accounting, audit, auditing firms. JEL Codes: M40, M41, M42

\section{INTRODUCTION}

An independent audit is an examination of the financial records, accounts, business transactions, accounting practices by an "independent" auditor. According to Flint (1988) the original purpose of auditing was to find out if certain duties were met honestly, with properness and in accordance with regulations and specific instructions. Companies prepare their financial statements in accordance with a framework of generally accepted accounting principles (GAAP) relevant to their country, also referred as accounting standards or financial reporting standards. Auditing can be seen as a special kind of examination that is a part of securing accountability, performed by a person other than the parties involved.

For as long as humans have existed, there has been technological development. During the recent years, the development of technology and digitalization have led to the globalization of business world especially accounting profession. It is important to realize how the accounting and audit profession is affected by technology and digitalization.

What impact digitalization will have on the audit profession is unknown, in that it is still a growing event. However, in the report prepared by FAR (2016), they anticipate that the automation and digitization of the accounting field will bring about structural changes that will have a profound impact on the entire audit profession. FAR (2016) insists that further development is necessary, but "One thing we know for certain is that our time is not close to what the future will be" (FAR, 2016).

In recent years, digitization has been seen as one of the most important events that will have a major impact on the audit profession and will lead to changes. In this study, current status of the audit profession in Turkey will be examined. In addition, the effect of digitalization on the audit profession will be determined. 


\section{LITERATURE REVIEW}

Kiesow et al. (2014) developed Continuous Auditing (CA) approach to cover the requirements to AIS in Big Data Computing Environments in their study. Since, the implementation of CA is a recognized challenge among researchers and practitioners, and traditional audit tools and techniques neglect the potential of Big Data Analytics, they strived for the development of appropriate computer-assisted audit tools and techniques (CAATTs). Therefore, they analyzed established CAATTs considering the dimensions of the Big Data paradigm in their research. To do so, they analyzed relevant literature and viewpoints of occupational organizations. They proposed a model for the integrated audit approach.

Alles and Gray (2015) aim to provide a balanced discussion of both the pros and the cons regarding incorporating Big Data into financial statement audits; and present a research agenda to identify specific aspects of Big Data that could benefit auditors.

Issa et al. (2016) propose various areas of Al-related research to examine where this emerging technology is most promising. Moreover, the paper raises a series of methodological and evolutionary research questions aiming to study the Al-driven transformation of today's world of audit into the assurance of the future.

Aslan and Özerhan (2017) reveal definition of Big Data, opportunities, challenges, accounting practices and its effects on accounting profession. According to the demographic factors, the perspectives of professional accountants operating in Turkey have been determined through a questionnaire about the impact of Big Data on accounting profession in next 10 years. The questionnaire was applied to 790 professional accountants and 740 valid questionnaires were taken into consideration. According to the results, accounting profession have different views about the effects of the BIG DATA on accounting profession over the next 10 years according to the demographic variables such as generation, gender, professional experience, place of residence, graduated faculty and working styles.

Karlsen and Wallberg (2017) aim to increase the understanding of the effects digitalization has on the tools and working methods of the audit profession. This is achieved through 14 semi-structured interviews with practicing auditors, where emphasis is put on interpretation. Conclusions drawn are that the effect on the auditors' working methods are more prominent than on the tools, due to paperless working methods and increased flexibility. Unlike previous research, this study also discovers an increasing effect - education. Thereby, education is underlined as important among auditors, where institutions also have to develop available education to the new competence needed.

Turker (2018) explains the developments and studies on shaping the global accounting profession to meet the expectations of the global business world according to the digital world.

Sabillon, R et al. (2017) examined the best practices and methodologies of global leaders in the cybersecurity assurance and audit arena. The article presents an original and comprehensive cybersecurity audit model as a proposal to be utilized for conducting cybersecurity audits in organizations and Nation States. The Cybersecurity Audit Model (CSAM) evaluates and validates audit, preventive, forensic and detective controls for all organizational functional areas. They tested, implemented and validated CSAM along with the Cybersecurity Awareness Training Model (CATRAM) in a Canadian higher education institution.

Uçma and Kurt (2018) discuss innovations brought by block-chain technology into the field of accounting and control. Then the study addresses the necessity of preparing professional members' future record keeping system on the basis of block-chain technology. Thus, the study draws attention to block-chain-based accounting and auditing practices and explains the professional qualification requirements that each member of the profession shapes in response to this innovation.

\section{DATA AND METHODOLOGY}

The aim of exploratory study is to increase the understanding of the effects digitalization has on the tools and working methods of the audit profession. For this purpose, websites of 235 audit firms authorized by KGK (Kamu Gözetimi Kurumu- Public Oversight, Accounting and Auditing Standards Authority) were examined.

The status of the services provided by the audit companies after the technological developments were analyzed. In addition, infrastructure and continuous education investments of audit firms related to digitalization have been determined.

The sample we used consists of the 235 of the 273 audit firms ( 38 firms' web sites could not be reached) which are listed in KGK's (Public Oversight, Accounting and Auditing Standards Authority) web site. The distribution of 235 companies by cities and authorization information of the firms are shown:

Table 1: Distribution of Audit Companies by Cities

\begin{tabular}{|l|c|c|c|}
\hline Cities & \# of Audit Firm & Cities & \# of Audit Firm \\
\hline İstanbul & 132 & Adana & 1 \\
\hline Ankara & 38 & Denizli & 1 \\
\hline İzmir & 18 & Elazı̆ & 1 \\
\hline Bursa & 13 & Eskişehir & 1 \\
\hline Antalya & 8 & Kocaeli & 1 \\
\hline Gaziantep & 7 & Kütahya & 1 \\
\hline Kayseri & 3 & Malatya & 1 \\
\hline Samsun & 3 & Manisa & 1 \\
\hline Şanlıurfa & 2 & Mersin & 1 \\
\hline Sakarya & 1 & Tekirdağ & \\
\hline
\end{tabular}


According to Table 1, There are 20 different cities where audit firms locate. Most of the audit firms operate in Istanbul (132 firms). Istanbul is followed by Ankara and Izmir (respectively 38, 18 firms).

Table 2: Authorizations of Audit Companies

\begin{tabular}{|l|c|}
\hline Authorization & \# of Audit firm \\
\hline Basic Audit Power & 115 \\
\hline Audit Power on PIE's Additionally Excluding Insurance Etc. & 64 \\
\hline Audit Power on PIE's Additionally & 56 \\
\hline Total & $\mathbf{2 3 5}$ \\
\hline
\end{tabular}

As shown in Table 2, 115 audit firms have only basic audit power. 64 of the other 120 companies have Audit Power on PIE's Additionally Excluding Insurance Etc. and rest of the firms have Audit Power on PIE's Additionally.

\section{FINDINGS}

Initially, to analyze the effects of digitalization on audit profession and services 235 companies' website disclosure were examined and services provided by firms detected.

Table 3: Services Provided by Audit Firms

\begin{tabular}{|l|c|}
\hline Services & \# of Audit Firms \\
\hline Independent Audit & 227 \\
\hline Tax Audit & 202 \\
\hline Corporate Finance/Financial Services & 145 \\
\hline Internal Audit/Internal Control & 106 \\
\hline Risk Management & 42 \\
\hline Digitalization/Information Technologies & 24 \\
\hline Other & 67 \\
\hline
\end{tabular}

As shown in the table above, unsurprisingly almost all of the firms provide independent audit and tax audit. At the same time, more than half of the companies perform advisory services in corporate finance and internal audit issues. Only 24 firms have services about Digitalization/Information Technologies. Approximately 90 percent of the sample have no disclosure about Digitalization/Information Technologies services.

Table 4: Digitalization/ Information Technology Services Provided by Firms

\begin{tabular}{|l|c|}
\hline Services & \# of Audit Firms \\
\hline IT Audit & 20 \\
\hline Cyber Security & 13 \\
\hline Big data/Data Analytics & 8 \\
\hline Digitalization & 7 \\
\hline Artificial Intelligence & 5 \\
\hline Blockhain & 5 \\
\hline Cloud Computing & 5 \\
\hline ERP & 5 \\
\hline loT & 1 \\
\hline Robotic Process Automation & 1 \\
\hline Social Media Audit & 1 \\
\hline
\end{tabular}

When the disclosures of the companies providing services on digitalization issues are examined, it is seen that IT audit and cyber security are the leading services. Big four provide services about promising and developing digitalization issues which are big data, Al, Blockchain, Cloud Computing and ERP. And also they disclose infrastructure investments about these topics.

\section{CONCLUSION}

In this study websites of 235 audit firms authorized by KGK and transparency reports of 64 companies authorized for PIE audit were investigated to determine current situation of effects digitalization has on the tools and working methods of the audit profession.

It has been concluded that almost all audit companies provide services for independent audit and tax audit. (Respectively $95 \%$ and $85 \%$ ). These are followed by financial services and internal audit issues. (Respectively $61 \%$ and $45 \%$ ).

Only Big Four invest the necessary infrastructure and human resources in addition to providing services in these matters. As a result, with the effect of digitalization, Information technologies have gained importance. But the audit firms have not yet made the necessary investment in these areas. $90 \%$ of audit firms do not provide services in these areas and do not make infrastructure and human resources investments. These audit firms are mainly focused on tax audit. The majority of customers are SMEs. It is quite natural that Big Four, which audit larger companies, make investments and services in these areas.

For further part of the study, the survey will be conducted to auditors to determine the effect of Digitalization on the audit profession. 


\section{REFERENCES}

Alles, M., \& Gray, G. L. (2015). The Pros and Cons of Using Big Data in Auditing: a Synthesis of the Literature and a Research Agenda. Awaiting Approval, 1-37.

Aslan, Ü., \& Özerhan, Y. (2017). Big Data, Muhasebe Ve Muhasebe Mesleği, Muhasebe Bilim Dünyası Dergisi, 19(4); 862-883

FAR. (2016). Nyckeln till framtiden. FAR. Retrieved from https://www.far.se/globalassets/trycksaker-pdf/nyckeln-till-framtiden_uppslag.pdf Flint, D. (1988). Philosophy and principles of auditing: An introduction. Macmillan Education LTD.

Issa, H., Sun, T., \& Vasarhelyi, M. A. (2016). Research Ideas for Artificial Intelligence in Auditing: The Formalization of Audit and Workforce Supplementation. Journal of Emerging Technologies in Accounting, 13(2), 1-20.doi:10.2308/jeta-10511

Karlsen A. \& Wallberg M. The effects of digitalization on auditors' tools and working methods: A study of the audit profession. http://www.diva-portal.org/smash/get/diva2:1115922/FULLTEXT01.pdf.

Kiesow, A., Zarvic, N., \& Thomas, O. (2014). Continuous Auditing in Big Data Computing Environments: Towards an Integrated Audit Approach by Using CAATTs. In GI-Jahrestagung pp. 901-912.

Sabillon, R., Serra-Ruiz, J., Cavaller, V., \& Cano, J. (2017). A Comprehensive Cybersecurity Audit Model to Improve Cybersecurity Assurance: The CyberSecurity Audit Model (CSAM). In 2017 International Conference on Information Systems and Computer Science (INCISCOS) (pp. 253-259). IEEE.

Türker, M. (2018). Dijitalleşme Sürecinde Küresel Muhasebe Mesleğinin Yeniden Şekillenmesine Bakış. World of Accounting Science, 20(1).

Uçma T., \& Kurt G., (2018). Blockchain Technology in Accounting and Auditing, Suleyman Demirel University The Journal of Faculty of Economics and Administrative Sciences, Vol.23, No.2, pp.467-481. 